\title{
HARDNESS OF NITRIDED LAYERS TREATED BY PLASMA NITRIDING
}

\author{
ZdenĚK Joska*, ZdenĚK Pokorný, JARomír KAdLec, ZbynĚK Studený, \\ EMIL SvOBODA
}

\author{
University of Defence, Faculty of Military Technology, Department of Mechanical Engineering, Kounicova 65, \\ 662 10 Brno, Czech Republic \\ * corresponding author: zdenek.joska@unob.cz
}

\begin{abstract}
Stainless steels, particularly the austenitic stainless grades are widely used in many industries due to good corrosion resistance, but very poor mechanical properties as surface hardness and wear resistance limit its possible use. Plasma nitriding is one of the few ways to increase the surface hardness of these steels, even though this will affect its corrosion resistance. This paper focuses on the description of the mechanical properties of nitrided layers in the two most widespread austenitic stainless steels AISI 304 and AISI 316L. The microstructure and properties of nitrided layers were evaluated by metallography and microhardness measurement. Surface properties of nitrided steels were characterized by Martens hardness. The results show that plasma nitriding created very hard nitrided layers with thickness about $40 \mu \mathrm{m}$ and microhardness about $1300 \mathrm{HV}_{0.05}$. Surface hardness measurements have shown that the maximum values for both steels are about $8.5 \mathrm{GPa}$, but have different behaviour under higher loads, when the AISI 316L nitrided layer began to crack on the surface and sink.
\end{abstract}

KEYWORDS: Austenitic stainless steel, microhardness, plasma nitriding.

\section{INTRODUCTION}

Plasma nitriding is one of the few technologies that allow us to increase the surface hardness and abrasion resistance of austenitic steels, and thanks to this surface treatment we can use austenitic stainless steels in other more demanding applications in industries such as chemical, petrochemical food or medical articles. [1 5] The issue of nitrided layers formed on austenitic steels has been intensively solved since the 1990 s, when the properties of these layers such as their depth, hardness, abrasion resistance and their influence on the corrosion resistance of steels are investigated. 6-10. Another possible application of such treated surfaces is as a transition layer between a soft backing material such as austenitic steels and a very hard and thin PVD coating [11 14. The aim of this paper is to describe the mechanical properties of nitrided layers formed on AISI 316L and 304 austenitic stainless steels.

\section{EXPERIMENT}

The AISI 304 steel samples were $50 \times 30 \mathrm{~mm}$ and $2 \mathrm{~mm}$ thick in the unprocessed state, and the $316 \mathrm{~L}$ steel had a $30 \mathrm{~mm}$ diameter and $7 \mathrm{~mm}$ thickness. The surface of the samples was ground and polished to a mirror finish and cleaned in an ultrasonic bath. The values of the chemical composition are given in Tab. 1 Subsequently, the samples were nitrided in plasma furnace Rübig PN 60/60 at condition see Tab. 2 Sputter cleaning was conducted in an $\mathrm{Ar}-\mathrm{H}_{2}$ atmosphere prior to plasma nitriding with a pulsed
- DC glow discharge. All samples were cooled after plasma nitriding in vacuum.

Depth profiles of plasma nitrided layers were measured by GDOES/QDP method. GDOES measurements were performed in LECO SA-2000 equipment. Calibration of nitrogen: JK41-1N and NSC4A standards were used. Confocal laser microscope LEXT OLS 3000 was used for observation of the cross section morphology of nitrided layers. The microhardness profile was measured on the LECO AMH 47 automatic microhardness tester. The Vickers indenter was selected, the load was $0.049 \mathrm{~N}$, dwell time at load was $12 \mathrm{~s}$. The profile of microhardness was measured at 5 locations on each sample.

Surface hardness of nitrided samples was measured on the instrument Zwick ZHU 2.5. The Martens hardness of nitrided layers in macroscale was determined. Vickers indenter was used, load was $196 \mathrm{~N}$, dwell time at load of $12 \mathrm{~s}$. Average value was determined from five measurements.

\section{RESUlts}

The nitriding process was carried out under specified conditions; Methane was added to the nitriding atmosphere during the nitriding process. GDOES measurements (Figs. 1, 2) showed that the plasma nitrided layer had a different chemical composition than the layer formed during standard nitriding. In both steels there were 1 zone in the nitrided layer where the amount of carbon increased. In AISI 304 steel, this zone occurred at a depth of about $10 \mathrm{\mu m}$ below 


\begin{tabular}{lllllllll}
\hline \multicolumn{10}{c}{ Chemical composition (wt\%) } \\
\hline & $\mathrm{C}$ & $\mathrm{Mn}$ & $\mathrm{Cr}$ & $\mathrm{Ni}$ & $\mathrm{Si}$ & $\mathrm{P}$ & $\mathrm{S}$ & $\mathrm{Mo}$ \\
AISI 304 & 0.045 & 1.78 & 18.7 & 8.75 & 0.48 & 0.030 & 0.001 & - \\
AISI 316 L & 0.03 & 1.50 & 16.97 & 10.70 & 0.31 & 0.030 & 0.026 & 2.18 \\
\hline
\end{tabular}

TABLE 1. Chemical composition of stainless steels

\begin{tabular}{lll}
\hline & Cleaning & Nitriding \\
\hline Temperature $\left({ }^{\circ} \mathrm{C}\right)$ & 520 & 550 \\
Duration (hours) & 0.5 & $8 \mathrm{~h}$ \\
Flow $\mathrm{H}_{2}\left(\mathrm{l} / \mathrm{min}^{-1}\right)$ & 20 & 8 \\
Flow $\mathrm{N}_{2}\left(\mathrm{l} / \mathrm{min}^{-1}\right)$ & 2 & 32 \\
Flow $\mathrm{CH}_{4}(\mathrm{l} / \mathrm{h})$ & 0 & 1.5 \\
Bias $(\mathrm{V})$ & 800 & 530 \\
Pulse length $(\mu \mathrm{s})$ & 100 & 100 \\
Pressure $(\mathrm{Pa})$ & 80 & 280 \\
\hline
\end{tabular}

TABLE 2. Parameters of plasma nitriding process

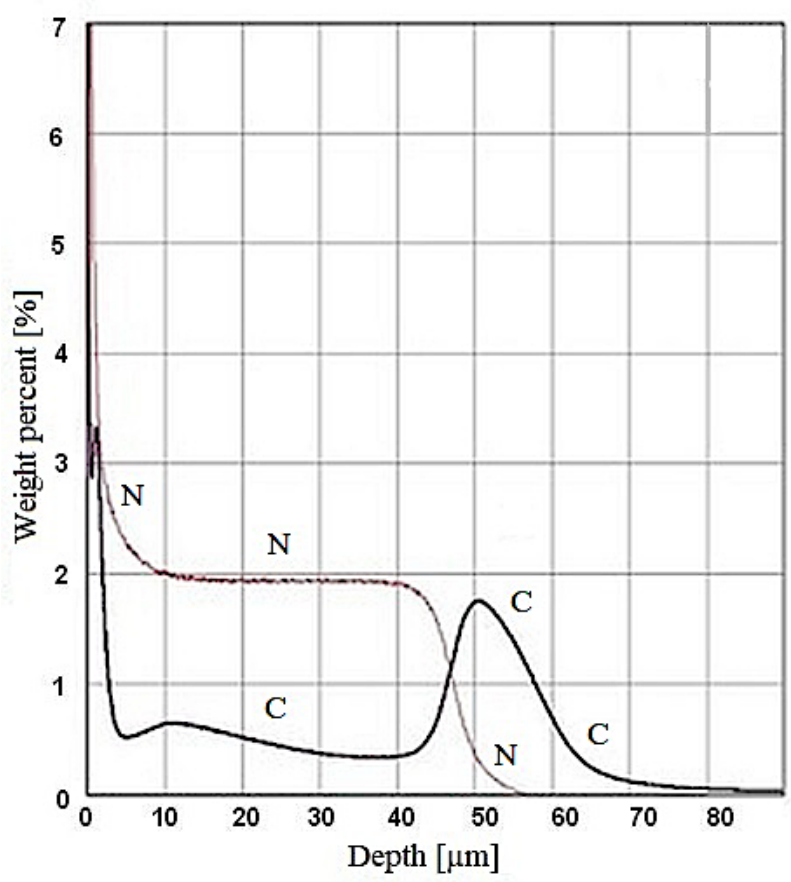

FIGURE 1. GDOES depth profile of nitrided AISI 304steel

the surface, and this layer is very well visible in Fig. 3 . The second significant zone is below the nitrided layer; this significant zone was formed during the diffusion process as carbon atoms are displaced nitrogen atoms. In AISI 316L steel, a zone of higher carbon content was also found at a depth of $15 \mu \mathrm{m}$ below the surface, but it is not apparent in the cross-section Fig. 4. It can be clearly seen from Fig. 4 that the diffusion layer formed has a different character at the bottom, not as sharply delimited as the AISI 304 steel. The total layer thickness of the AISI 304 steel was $45 \mu \mathrm{m}$. In AISI 316L steel the nitrided layer reached a thickness of $40 \mu \mathrm{m}$.

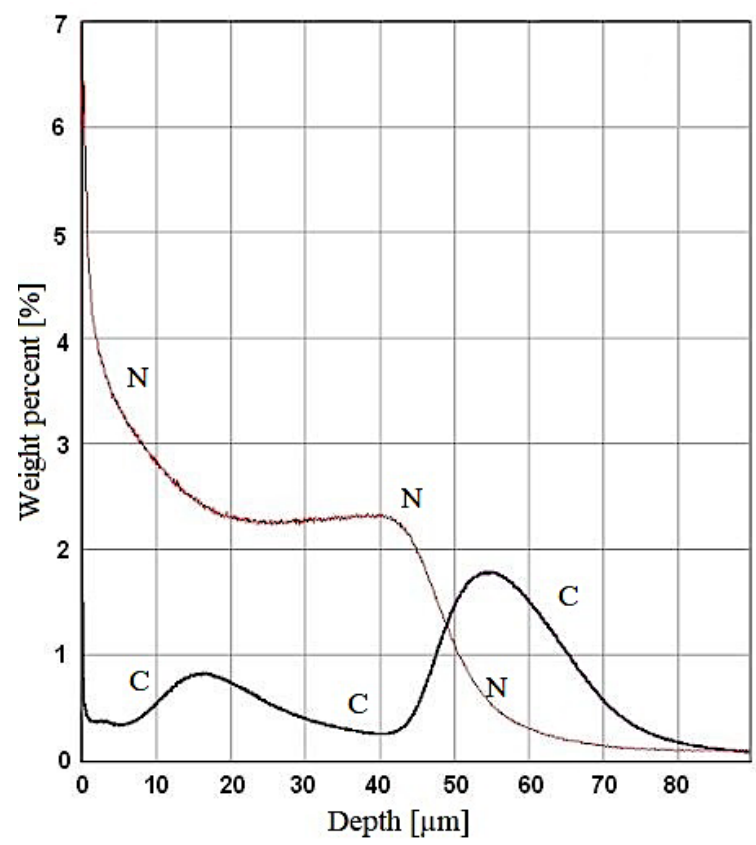

FIgURE 2. GDOES depth profile of nitrided AISI 316L steel

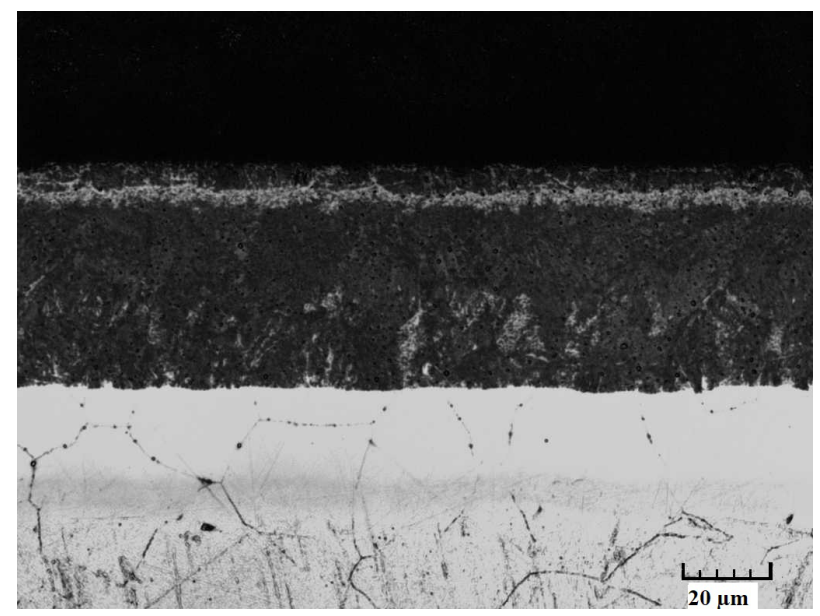

FigURE 3. Micrographs of the nitrided layer of the AISI 304 steel

The thickness and profile of the nitrided layers were measured by microhardness see Fig. 5, 6, thickness of both nitrided layers of AISI 304 and AISI 316L were in good agreement with cross section morphology. The highest values of microhardness were similar but for AISI 316L was higher, reached $1383 \mathrm{HV}_{0.05}$ and for AISI 304 the highest values of microhardness reached $1200 \mathrm{HV}_{0.05}$.

The highest values of surface hardness were the 


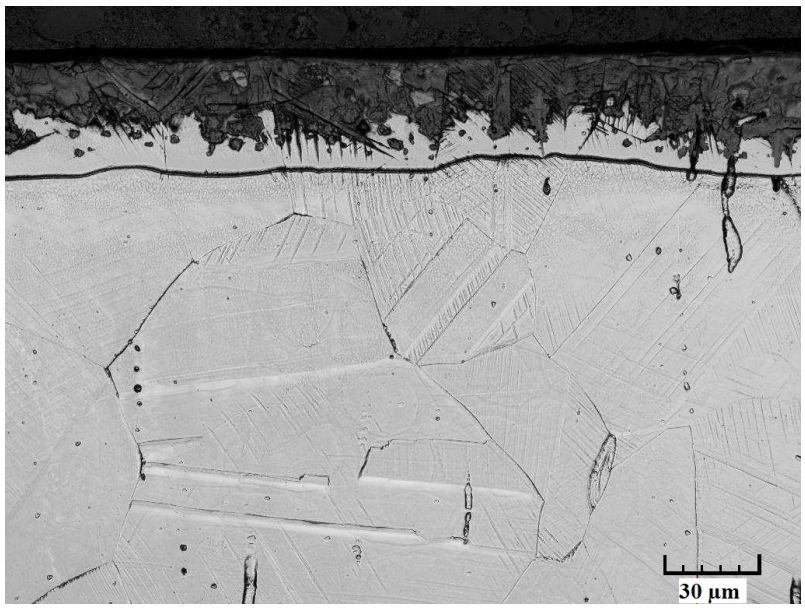

Figure 4. Micrographs of the nitrided layer of the AISI 316L steel

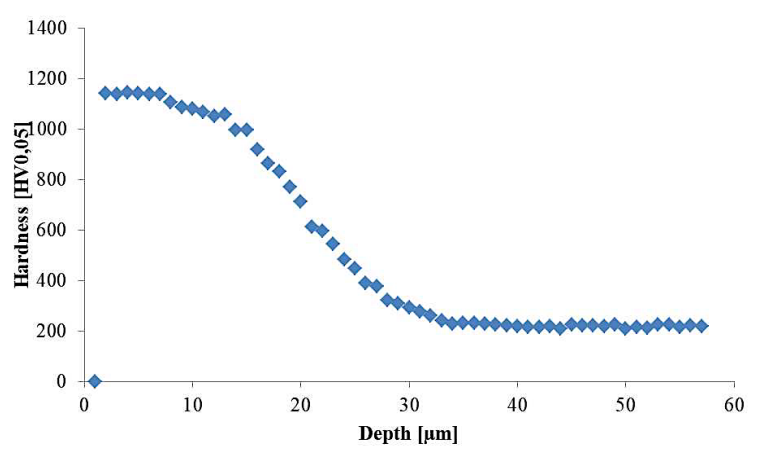

FigURE 5. Microhardness profile of nitrided AISI 304 steel

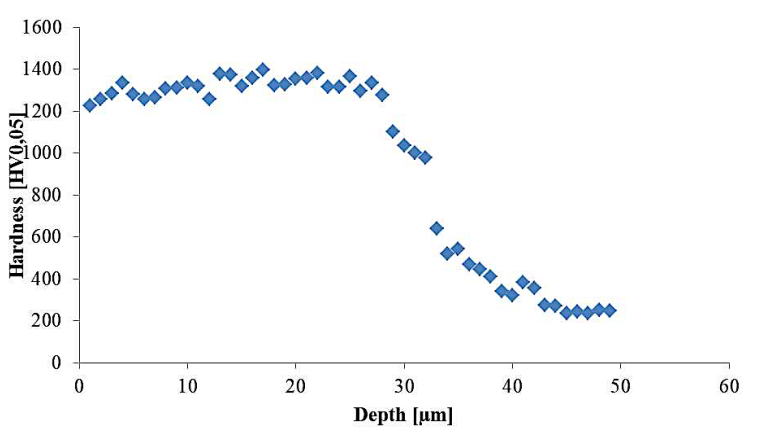

FiguRE 6. Microhardness profile of nitrided AISI 316L steel

same for both of the steels reached 8.5 GPa. As can be seen from the graphs Fig. 7 8, each nitrided layer behaved differently during loading. With the AISI 304 material, the curve to an indentation depth of about 6 micrometres was stable and then gradually decreased with increasing indentation depth. Thus, in the case of AISI 316L, the curve was diametrically different; the layer exhibited stability to an indentation depth of about $15 \mu \mathrm{m}$ and then ruptured and continued to crack even at an increasing indentation depth.

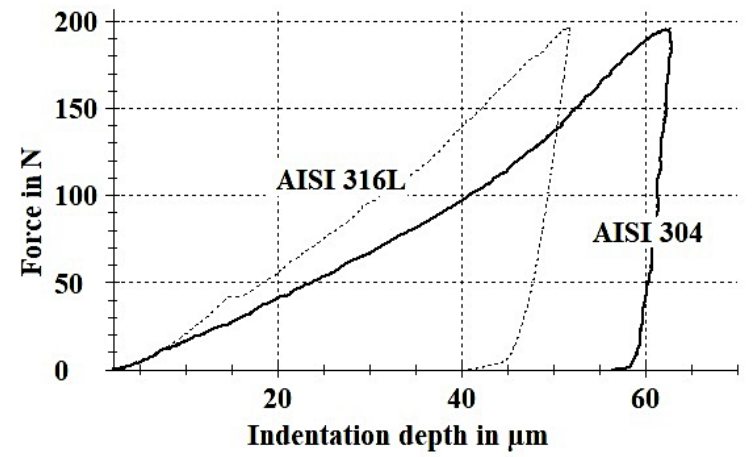

FiguRE 7. Force - displacement curve of nitrided layers

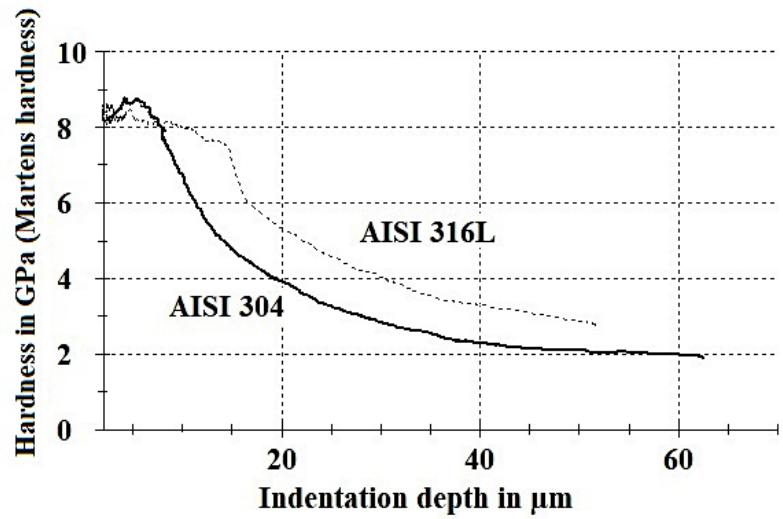

Figure 8. Hardness vs indentation depth of nitrided layers

\section{Conclusions}

The results of the experiment showed that plasma nitriding creates a sufficiently deep nitrided layer on both steels that can be used as a transition layer between a soft substrate and a PVD coating. In AISI 316L steel, the nitrided layer has more suitable properties because it achieves higher hardness and thickness of nitrided layer than AISI 304 steel nitrided layer which has lower microhardness and thickness and in addition, at higher loads, the surface of the nitrided layer is broken.

\section{ACKNOWLEDGEMENTS}

The paper has been prepared thanks to the support of the project The Development of Technologies, Design of Firearms, Ammunition, Instrumentation, Engineering of Materials and Military infrastructure "Výzbroj (DZRO K201)".

\section{REFERENCES}

[1] K. Lo, C. Shek, J. Lai. Recent developments in stainless steels. Materials Science and Engineering: R: Reports 65(4-6):39-104, 2009. DOI:10.1016/j.mser.2009.03.001.

[2] T. Czerwiec, N. Renevier, H. Michel. Low-temperature plasma-assisted nitriding. Surface and Coatings Technology 131(1-3):267-277, 2000. DOI:10.1016/s0257-8972(00)00792-1. 
[3] J. Kadlec, M. Dvorak. Duplex surface treatment of stainless steel x12crni 18 8. Strength of Materials 40(1):118-121, 2008. DOI:10.1007/s11223-008-0031-y

[4] K. Lin, X. Li, H. Dong, et al. Surface modification of 316 stainless steel with platinum for the application of bipolar plates in high performance proton exchange membrane fuel cells. International Journal of Hydrogen Energy 42(4):2338-2348, 2017. DOI:10.1016/j.ijhydene.2016.09.220

[5] C. Li, T. Bell. Sliding wear properties of active screen plasma nitrided 316 austenitic stainless steel. Wear 256(11-12):1144-1152, 2004. DOI:10.1016/j.wear.2003.07.006

[6] J. Baranowska. Characteristic of the nitride layers on the stainless steel at low temperature. Surface and Coatings Technology 180-181:145-149, 2004. DOI:10.1016/j.surfcoat.2003.10.056

[7] J. Wang, J. Xiong, Q. Peng, et al. Effects of DC plasma nitriding parameters on microstructure and properties of 3041 stainless steel. Materials Characterization 60(3):197203, 2009. DOI:10.1016/j.matchar.2008.08.011

[8] I. Lee. The effect of molybdenum on the characteristics of surface layers of low temperature plasma nitrocarburized austenitic stainless steel. Current Applied Physics 9(3):S257-S261, 2009. DOI:10.1016/j.cap.2009.01.030
[9] J. Stinville, P. Villechaise, C. Templier, et al. Plasma nitriding of 3161 austenitic stainless steel: Experimental investigation of fatigue life and surface evolution. Surface and Coatings Technology 204(12-13):1947-1951, 2010. DOI:10.1016/j.surfcoat.2009.09.052

[10] Z. Joska, J. Kadlec, V. Hruby, et al. Characteristics of duplex coating on austenitic stainless steel. Key Engineering Materials 465:255-258, 2011. DOI:10.4028/www.scientific.net/kem.465.255

[11] Z. Joska, M. Pospíchal, T. Mrázková, J. Sukáč. Mechanical properties of duplex system: Zrn coating on plasma nitrided stainless steel. Chemické listy 104:322-325, 2010.

[12] E. Dalibon, D. Heim, C. Forsich, S. Br uhl. Mechanical behavior of nitrided $316 \mathrm{l}$ austenitic stainless steel coated with a:c-h-si. Procedia Materials Science 9:163-170, 2015. DOI:10.1016/j.mspro.2015.04.021.

[13] Metallic materials - instrumented indentation test for hardness and material parameters - part 1: Test method. CSN EN ISO 14577-1:2015 .

[14] J. Stinville, C. Tromas, P. Villechaise, C. Templier. Anisotropy changes in hardness and indentation modulus induced by plasma nitriding of 3161 polycrystalline stainless steel. Scripta Materialia 64(1):37-40, 2011. DOI:10.1016/j.scriptamat.2010.08.058 